\title{
Analysis of the Sulfur Dioxide Column Concentration over Jing-Jin-Ji, China, Based on Satellite Observations during the Past Decade
}

\author{
Yanfang Hou, Litao Wang, Yi Zhou*, Shixin Wang, Feng Wang \\ Institute of Remote Sensing and Digital Earth, Chinese Academy of Sciences, Beijing 100101, China
}

Received: 13 July 2017

Accepted: 15 September 2017

\begin{abstract}
Atmospheric sulfur dioxide $\left(\mathrm{SO}_{2}\right)$ is a major air pollutant and has the most negative effect on atmospheric chemistry. In this study, measurements of $\mathrm{SO}_{2}$ column concentration obtained from an ozone monitoring instrument (OMI) are used to investigate the temporal and spatial dynamics of $\mathrm{SO}_{2}$. Temporal and spatial distributions of $\mathrm{SO}_{2}$ concentrations obtained from OMI over the Beijing-Tianjin-Hebei (Jing-Jin-Ji) region from 2007 to 2016 are presented, and annual changes and trends in the seasonal cycle are shown. The annual variations of $\mathrm{SO}_{2}$ concentration are found to have decreased $47.6 \%$ from 2007 to 2016, and the $\mathrm{SO}_{2}$ concentration shows a high correlation with $\mathrm{SO}_{2}$ emissions. $\mathrm{SO}_{2}$ shows significant cyclical seasonal characteristics over Jing-Jin-Ji, with maximum values in winter and minimum in summer; both temperature and precipitation are negatively correlated with $\mathrm{SO}_{2}$ concentrations in seasonal variations. In addition, the spatial distribution is unbalanced, and Shijiazhuang-Xingtai-Handan is found to be in highly polluted areas, which may be related to energy consumption. The overall trends in the average annual value of $\mathrm{SO}_{2}$ in the 13 sites appear to have decreased since 2007, and $\mathrm{SO}_{2}$ concentrations in the Shijiazhuang-Xingtai-Handan region decreased by $55 \%$ during the past decade, so the Chinese government has made great efforts in pollution reduction, and has achieved remarkable results.
\end{abstract}

Keywords: satellite remote sensing, $\mathrm{SO}_{2}$ column concentration, OMI, spatiotemporal variations, Jing-Jin-Ji

\section{Introduction}

Atmospheric sulfur dioxide $\left(\mathrm{SO}_{2}\right)$ is one of the most important trace gases in the atmosphere, and it has a significant impact on the environment and climate [12]. $\mathrm{SO}_{2}$ in the troposphere is known to cause a variety of adverse environmental and human health effects [3].

*e-mail: zhouyi@radi.ac.cn
$\mathrm{SO}_{2}$ is a major acid rain precursor, and its oxidation product, sulphate, plays an important role in radiative forcing of the climate [4-5]. The variation in $\mathrm{SO}_{2}$ concentration is controlled by a number of complex factors, which mainly include natural sources (degassing and eruptions of volcanoes, sea spray) and anthropogenic sources (combustion processes) [6-8]. It is estimated that anthropogenic sources account for more than $70 \%$ of $\mathrm{SO}_{2}$ global emissions, half of which are from fossil-fuel combustion [9]. During the past two decades China has experienced rapid economic growth, and this process is 
driven by fossil fuel consumption, which releases large volumes of air pollutants into the atmosphere, leading to a series of complex air pollution problems such as acid rain, haze, and photochemical smog [10-11].

Compared to ground networks, satellite observations have been widely acknowledged as one of the most important tools to quantitatively evaluate the longterm spatial and temporal distribution characteristics of atmospheric composition [12-13]. There have been a number of milestones in $\mathrm{SO}_{2}$ retrieval from space-based sensors, and $\mathrm{SO}_{2}$ has been measured from space since the 1982 eruption of El Chichón [14]. This was the first time when $\mathrm{SO}_{2}$ from satellite measurements could be determined from UV-VIS sensors. Those measurements were carried out by a total ozone mapping spectrometer (TOMS). Since then, next-generation space-borne spectrometers like GOME and GOME-2 (global ozone monitoring experiment), SCIAMACHY (scanning imaging absorption spectrometer for atmospheric chartography), and OMI (ozone monitoring instrument) have shown greatly improved $\mathrm{SO}_{2}$ detection sensitivity [8]. OMI provides daily, nearly global maps of vertical column densities of $\mathrm{SO}_{2}$, and has the highest spatial resolution, longest operation, and lowest degradation, and is the most sensitive to $\mathrm{SO}_{2}$ sources among the satellite instruments of its class [15].

In this study, we focus on the variations of $\mathrm{SO}_{2}$ column concentrations over the Beijing-Tianjin-Hebei (Jing-JinJi) region based on 10 years (2007-16) of $\mathrm{SO}_{2}$ column measurements from OMI. As China's high-pollution area, the Jing-Jin-Ji region has received more and more attention, while the Chinese government has also taken active measures to prevent pollution. The major objectives of this study are to study the temporal and spatial variations of $\mathrm{SO}_{2}$ column concentration over the Jing-Jin-Ji region, and to determine whether the energy savings and emissions reduction policy has affected a change in $\mathrm{SO}_{2}$ concentration.

\section{Material and Methods}

\section{Study Area}

The Jing-Jin-Ji region is located on the eastern coast of China and comprises the cities of Beijing and Tianjin, and Hebei Province (Fig. 1). According to the Hebei Economic Yearbook (2016), Jing-Jin-Ji covers an area of about $216,000 \mathrm{~km}^{2}$, has a population of 110 million, and in 2015 had a GDP of 690 billion yuan. It has a humid continental climate characterized by hot, humid summers and cold, dry winters [16]. Fig. 1 (right) shows the JingJin-Ji region comprising Beijing (BJ), Tianjin (TJ), Shijiazhuang (SJZ), Tangshan (TS), Qinhuangdao (QHD), Handan (HD), Xingtai (XT), Baoding (BD), Zhangjiakou (ZJK), Chengde (CD), Cangzhou (CZ), Langfang (LF), and Hengshui (HS).

\section{Data Sources}

The OMI, a contribution to the National Aeronautics and Space Administration's (NASA) Aura mission by the Netherlands Agency for Aerospace Programs (NIVR) in collaboration with the Finnish Meteorological Institute (FMI), is orbiting earth on the Aura spacecraft, which was launched in July 2004 from Vandenberg Air Force base in California into a polar sun-synchronous orbit [17]. The OMI combines the advantages of both GOME and SCIAMACHY and uses a total ozone mapping spectrometer. It measures the complete UV/VIS wavelength spectrum range daily with a very high spatial resolution $(13 \times 24 \mathrm{~km})$, and has the ability to measure both multiple trace gases and aerosol properties [18].

The $\mathrm{SO}_{2}$ inversion strategy is based on the statistical approach [19], and the strategy is to consider OMI measurements together with climatological data as a single set of multi-source data. The inversion technique is designed as a search for the best overall fit of all data considered by our forward model (in a least-squares sense) taking into account different accuracies of the fitted (measured and a priori) data [20]. The algorithm has been described in detail elsewhere [21-23].

The OMI Level-3 daily global $\mathrm{SO}_{2}$ data product, obtained from the NASA Goddard Earth Science Data and Information Services Center, is used in this study [24], with a data format of HDF-EOS 5 and a spatial resolution of $0.25 \times 0.25 \mathrm{deg}$. It extends from January 2007 to December 2016 and provides monthly coverage of the entire globe. Each grid contains only one observation of total column density of $\mathrm{SO}_{2}$ in the planetary boundary layer (PBL) based on an improved band residual difference (BRD) algorithm [23]. PBL corresponds to an altitude below $2 \mathrm{~km}$ with the central height being about $0.9 \mathrm{~km}$, and $\mathrm{SO}_{2}$ within this layer stems mostly from human activities [25]. After comparing $\mathrm{SO}_{2}$ concentration data acquired from airborne surveillance with synchronously acquired $\mathrm{OMI} \mathrm{SO}_{2}$ data in northeastern China in April 2005, [26] we concluded that daily OMI data could be used as a reliable surrogate for $\mathrm{SO}_{2}$ pollutants in the atmosphere.

Monthly mean air temperature and precipitation are provided by the National Climate Center of China. These datasets are available as an ASCII file that contains monthly mean temperatures and precipitation obtained

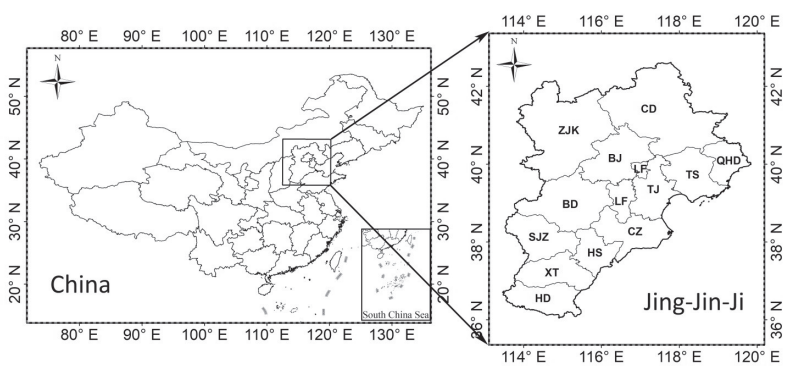

Fig. 1. Location of the study area. 

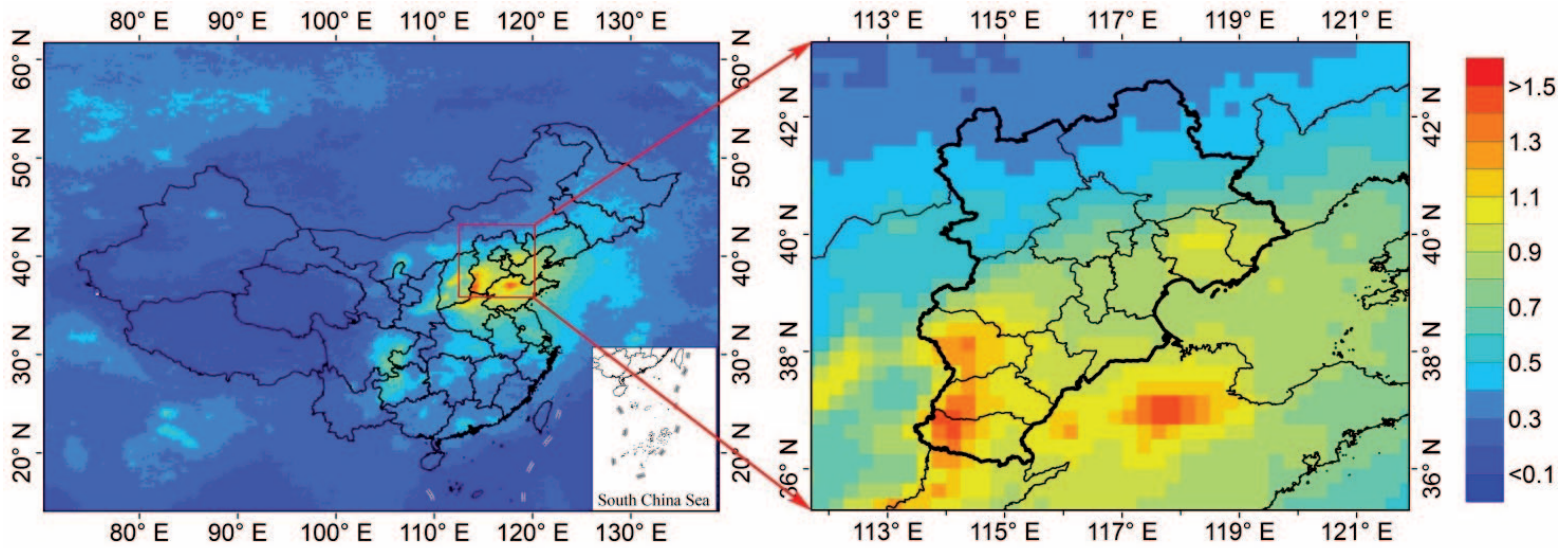

Fig. 2. Spatial distributions of $\mathrm{SO}_{2}$ concentrations (DU) over China (left) and Jing-Jin-Ji (right) during 2007-16.

from 160 stations over China since January 1951. All values within the datasets are integers with the unit of 0.1 centigrade and $1 \mathrm{~mm}$, respectively. Six of the stations are located in the Jing-Jin-Ji region, which include Beijing $\left(116.28^{\circ} \mathrm{E}, 39.93^{\circ} \mathrm{N}\right)$, Tianjin $\left(117.17^{\circ} \mathrm{E}, 39.10^{\circ} \mathrm{N}\right)$, Shijiazhuang $\left(114.42^{\circ} \mathrm{E}, 38.03^{\circ} \mathrm{N}\right)$, Chengde $\left(117.93^{\circ} \mathrm{E}\right.$, $\left.40.97^{\circ} \mathrm{N}\right)$, Zhangjiakou $\left(114.88^{\circ} \mathrm{E}, 40.78^{\circ} \mathrm{N}\right)$, and Xingtai $\left(114.50^{\circ} \mathrm{E}, 37.07^{\circ} \mathrm{N}\right)$.

This article also uses statistical datasets relating to $\mathrm{SO}_{2}$ emissions and energy consumption, which cover the period 2007 to 2015 in the Jing-Jin-Ji region and are collected from the 2011 and 2016 Hebei Economic Yearbooks.

\section{Results and Discussion}

Overall Trend of $\mathrm{SO}_{2}$

Fig. 2 shows the spatial distributions of average $\mathrm{SO}_{2}$ concentration over China (left) and Jing-Jin-Ji (right) during 2007-16. It is evident that the $\mathrm{SO}_{2}$ concentration in the Jing-Jin-Ji region is relatively higher (left column) than that over the whole of China, thereby showing that it is a polluted area and justifying its status as a focus of pollution research. As shown in the right column of Fig. 2, the $\mathrm{SO}_{2}$ concentration over the Jing-Jin-Ji region is prominent, the spatial distribution is unbalanced throughout China, and the Shijiazhuang-Xingtai-Handan area is highly polluted. Regions with higher $\mathrm{SO}_{2}$ are $\mathrm{SJZ}$, $\mathrm{XT}$, and $\mathrm{HD}$, and those with lower $\mathrm{SO}_{2}$ are $\mathrm{ZJK}$ and $\mathrm{CD}$.

Monthly variations of $\mathrm{SO}_{2}$ from OMI over Jing-JinJi during January 2007 to December 2016 are presented in Fig. 3a). Cyclical seasonal cycle characteristics are significant; the highest values occur in winter and the lowest in summer. The annual variations of $\mathrm{SO}_{2}$ over JingJin-Ji from 2007 to 2016 are presented in Fig. 3b). Yearly variations in the $\mathrm{SO}_{2}$ concentration over Jing-Jin-Ji are prominent, and the trend in the average annual value of $\mathrm{SO}_{2}$ appears to have decreased since 2007, which may be related to the strong control for pollution emissions. Since 1995 the Chinese government has placed great emphasis on controlling $\mathrm{SO}_{2}$ pollution [27]. New thermal power units as well as most existing ones must install flue gas desulfurization (FGD) systems, while small units with low energy effciency should be gradually shut down [2830]. There was a slight rise in $\mathrm{SO}_{2}$ level from 2010 to 2011, which might reflect the impact of anthropogenic activity. However, the concentration of $\mathrm{SO}_{2}$ declined year by year during the past decade, and $\mathrm{SO}_{2}$ concentration decreased $47.6 \%$ from 2007 to 2016, indicating that the Chinese government has made great efforts in pollution reduction.

A comparison between $\mathrm{SO}_{2}$ concentration and $\mathrm{SO}_{2}$ emissions over the Jing-Jin-Ji region during 2007-15 is presented in Fig. 4. According to the 2016 Hebei Economic Yearbook, the $\mathrm{SO}_{2}$ emissions have been reduced from 1.8 million tons (Mt) in 2007 to $1.3 \mathrm{Mt}$ in 2015. Changes of the $\mathrm{SO}_{2}$ concentration are consistent with the $\mathrm{SO}_{2}$ emissions (Fig. 4a), and the $\mathrm{SO}_{2}$ concentration shows a high correlation $\left(\mathrm{R}^{2}=0.978\right)$ to the $\mathrm{SO}_{2}$ emissions over Jing-Jin-Ji during 2007-15 (see Fig. 4b). So the Chinese government has made great efforts in pollution reduction, and has achieved remarkable results.

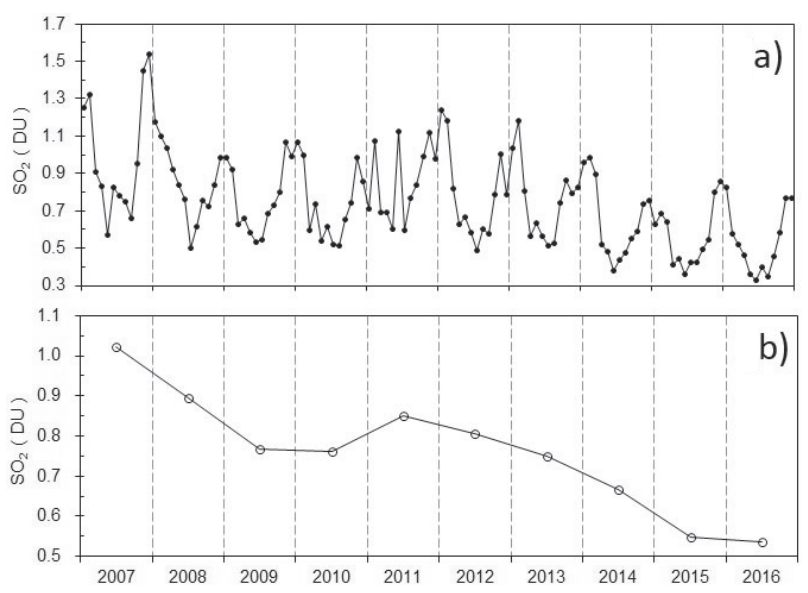

Fig. 3. a) Monthly variations of $\mathrm{SO}_{2}$ from OMI over Jing-Jin-Ji during January 2007 to December 2016; b) annual variations of $\mathrm{SO}_{2}$ over Jing-Jin-Ji from 2007 to 2016. 

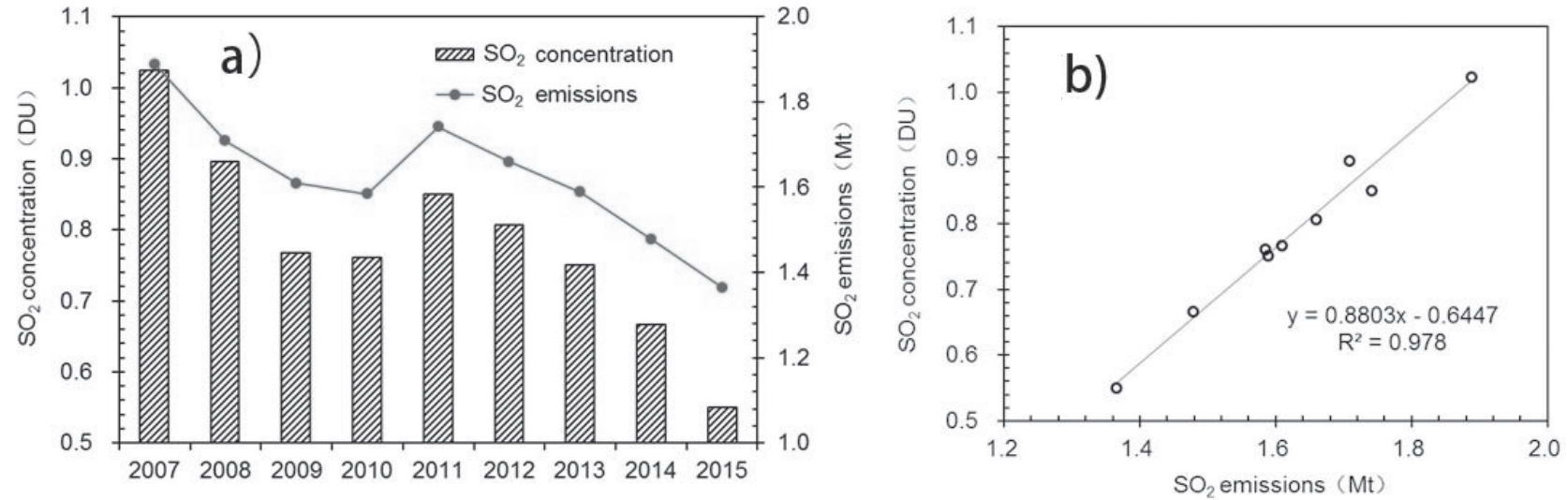

Fig. 4. Comparison between $\mathrm{SO}_{2}$ concentrations and $\mathrm{SO}_{2}$ emissions over the Jing-Jin-Ji region during 2007-15: a) changes in $\mathrm{SO}_{2}$ concentrations and $\mathrm{SO}_{2}$ emissions and $\mathrm{b}$ ) correlation between $\mathrm{SO}_{2}$ concentrations and $\mathrm{SO}_{2}$ emissions.

\section{Seasonal Variation}

The seasonal distribution of $\mathrm{SO}_{2}$ concentration over Jing-Jin-Ji based on OMI data of 2007-16 for the four seasons (spring: March, April, May; summer: June, July, August; autumn: September, October, November; winter: January, February, December) is shown in Figs. 5(a-d). Results show that the $\mathrm{SO}_{2}$ concentration over Jing-Jin-Ji was higher in winter and lower in summer. However, the seasonal spatial distribution is unbalanced, and the high pollution areas are found to be Shijiazhuang-XingtaiHandan; these results are in agreement with the annual average distribution (Fig. 2, right).

The seasonal cycle characteristics are also seen in Fig. 3a), where a maximum is apparent in winter and a minimum in summer, and the lowest $\mathrm{SO}_{2}$ values are generally apparent in June and July, but are highest in January and December. Fig. 6 shows the annual changes
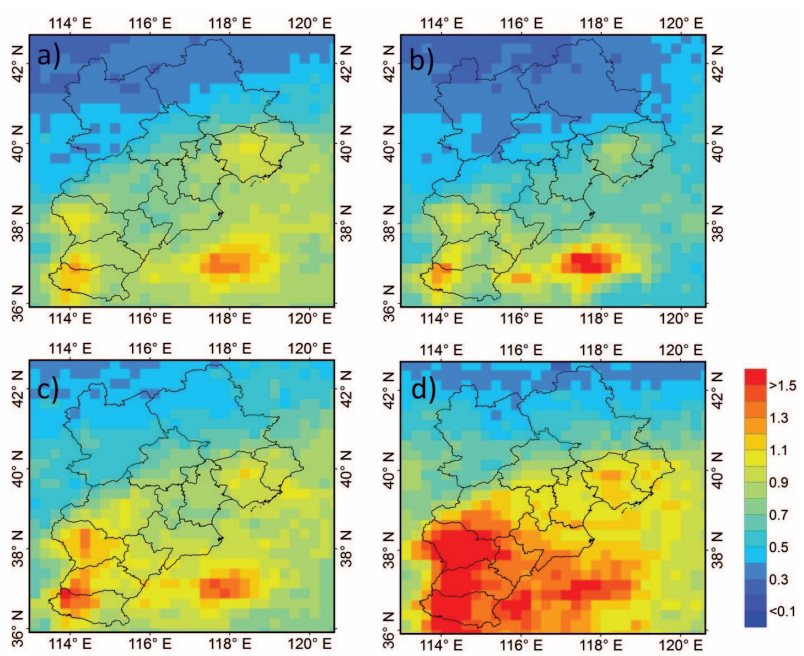

Fig. 5. Seasonal distribution of $\mathrm{SO} 2$ concentrations (DU) over Jing-Jin-Ji based on OMI data during 2007-16: a) spring, b) summer, c) autumn, d) winter. of $\mathrm{SO}_{2}$ over four seasons in the Jing-Jin-Ji region based on OMI data during 2007-16. Significant differences are evident, and there is a maximum in winter and a minimum in summer. A sudden increase in the $\mathrm{SO}_{2}$ concentration occurred in the summer of 2011, which may be related to human activity.

Meteorological factors are the key factors influencing the seasonal variations of the concentration of pollutants. A comparison between temperature, precipitation, and seasonal signals of $\mathrm{SO}_{2}$ over the Jing-Jin-Ji region during 2007-16 are shown in Fig. 7, where it is evident that the seasonal characteristics are prominent; temperature and precipitation have similar seasonal circulation characteristics, and the seasonal variation in the $\mathrm{SO}_{2}$ concentration has the opposite characteristics. The seasonal signal of $\mathrm{SO}_{2}$ over the Jing-Jin-Ji region decreased to a minimum in spring or summer every year and then gradually increased to a maximum in winter (Fig. 7b). In addition, the Jing-Jin-Ji region has a greater amount of precipitation in summer (Fig. 7c).

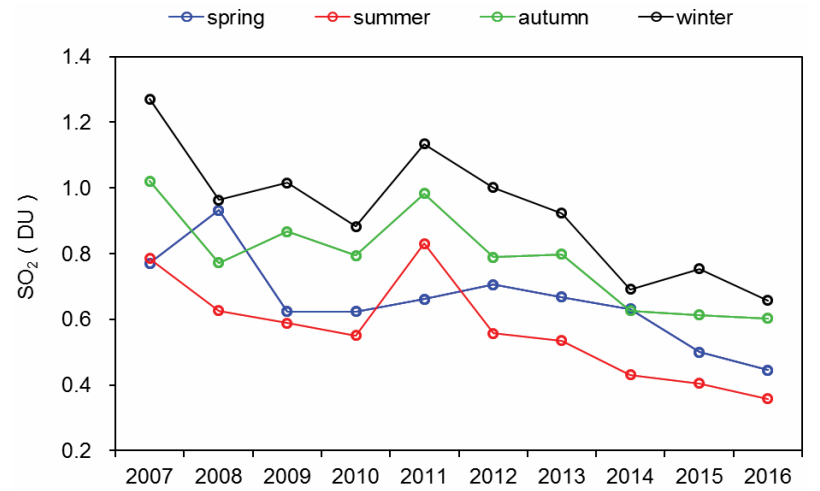

Fig. 6. Annual changes of $\mathrm{SO}_{2}$ over four seasons in the Jing-JinJi region based on OMI data during 2007-16. 

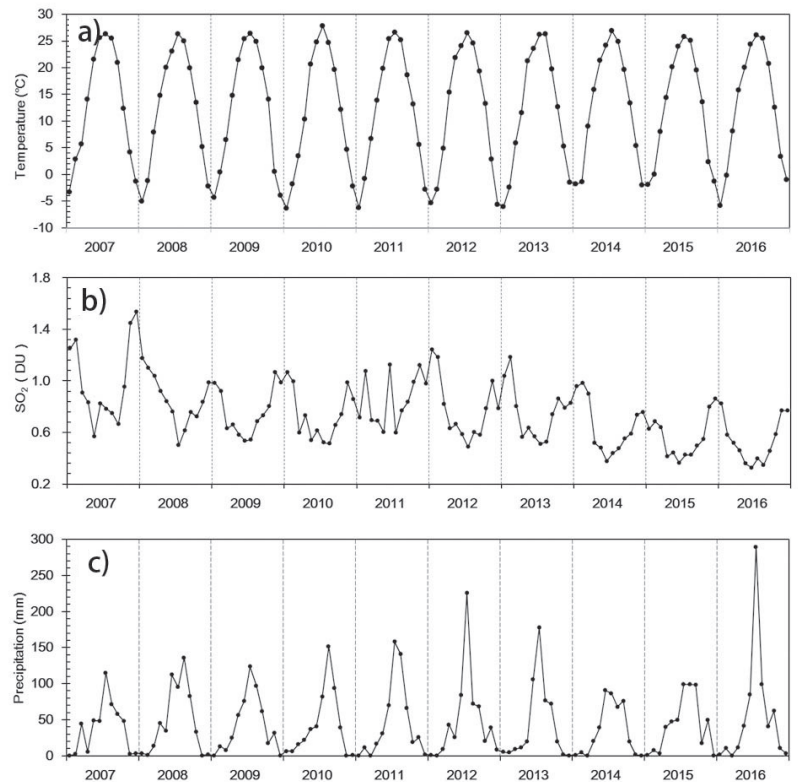

Fig. 7. Comparison between temperature, precipitation, and seasonal signals of $\mathrm{SO}_{2}$ over the Jing-Jin-Ji region during 2007 16: a) time series of monthly means of temperature derived from surface-monitoring stations, $b$ ) time series of monthly means of $\mathrm{SO}_{2}$ derived from OMI data, and c) time series of monthly means of precipitation derived from surface-monitoring stations.
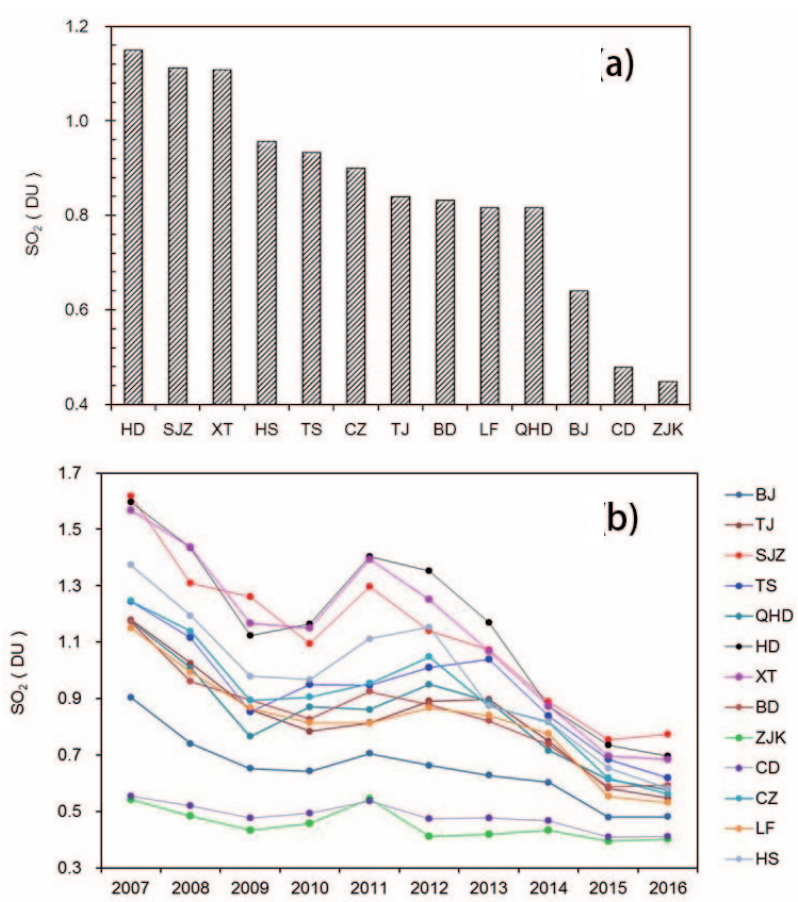

Fig. 8. a) Variations of $\mathrm{SO}_{2}$ concentrations over the 13 regions during 2007-16, b) annual changes of $\mathrm{SO}_{2}$ concentrations in 13 major cities of Jing-Jin-Ji based on OMI data during 2007-16.

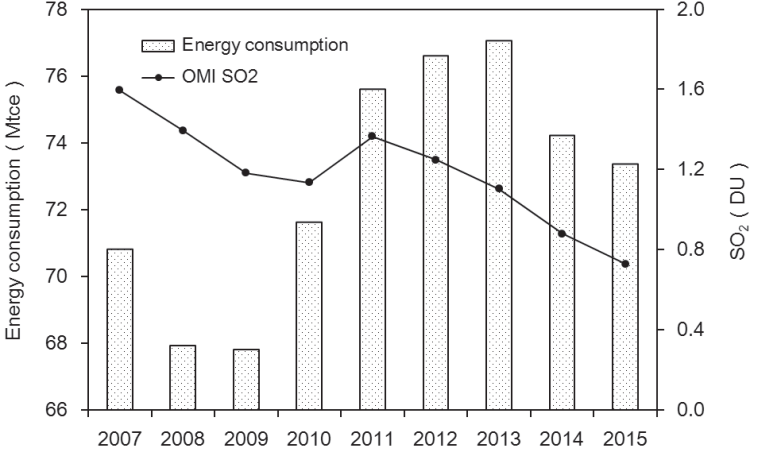

Fig. 9. Comparison between energy consumption and $\mathrm{SO}_{2}$ concentrations over the Shijiazhuang-Xingtai-Handan region during 2007-15.

\section{Regional Change Characteristics of $\mathrm{SO}_{2}$}

Variations of $\mathrm{SO}_{2}$ concentration over the 13 regions during 2007-16 are presented in Fig. 8a). The regions with higher $\mathrm{SO}_{2}$ are located in $\mathrm{HD}, \mathrm{SJZ}$, and XT, and those with lower $\mathrm{SO}_{2}$ are $\mathrm{ZJK}$ and $\mathrm{CD}$, which is in agreement with the annual average distribution (Fig. 2, right). Fig. $8 b)$ presents the annual changes of $\mathrm{SO}_{2}$ concentration in 13 major cities of Jing-Jin-Ji based on OMI data during the period 2007-16. Yearly variations in the $\mathrm{SO}_{2}$ concentration over the 13 major cities are prominent, and the overall trends in the average annual value of $\mathrm{SO}_{2}$ in the 13 cities appear to have decreased since 2007. There was a slight rise in $\mathrm{SO}_{2}$ level from 2010 to 2011, which is consistent with the $\mathrm{SO}_{2}$ concentration of Jing-Jin-Ji (see Fig. 3b).

The Shijiazhuang-Xingtai-Handan region is an important industrial area of Hebei Province, and energy consumption may be a major source of the fastincreasing levels of pollution gases. Fig. 9 shows the comparison between energy consumption and $\mathrm{SO}_{2}$ over the Shijiazhuang-Xingtai-Handan region during 2007-15. Yearly variations in energy consumption (unit: million tonnes of coal equivalent - Mtce) over the Shijiazhuang-Xingtai-Handan region are prominent, with a rapid drop in 2008 and a rise in 2010, and then a yearly decline after 2013 . At the same time, yearly variations in $\mathrm{SO}_{2}$ concentration over the ShijiazhuangXingtai-Handan region appear to decrease, with a slight increase in 2011. So energy consumption has a certain relationship with $\mathrm{SO}_{2}$ concentration. As high pollution areas, the $\mathrm{SO}_{2}$ concentration in the Shijiazhuang-XingtaiHandan region decreased by $55 \%$ during the past decade.

\section{Conclusions}

This article describes the spatiotemporal variations of $\mathrm{SO}_{2}$ concentrations during 2007-16 over the Jing-Jin-Ji region in China using remote sensing data obtained from OMI. Results can be summarized as follows: 
1) The spatial distribution of $\mathrm{SO}_{2}$ was unbalanced; regions with high levels are located in SJZ, XT, and $\mathrm{HD}$, and those with low $\mathrm{SO}_{2}$ are ZJK and CD. In addition, Shijiazhuang-Xingtai-Handan is found to be a highly polluted area.

2) There are prominent yearly variations in concentrations of $\mathrm{SO}_{2}$. An overall decreasing trend in the average annual value of $\mathrm{SO}_{2}$ occurred (except for a slight rise in $\mathrm{SO}_{2}$ level from 2010 to 2011), and $\mathrm{SO}_{2}$ concentration variation based on satellite data shows a high correlation with $\mathrm{SO}_{2}$ emissions $\left(\mathrm{R}^{2}=0.978\right)$.

3) Amounts of $\mathrm{SO}_{2}$ over the Jing-Jin-Ji region showed significant seasonal cycle characteristics, with a maximum in winter and a minimum in summer. The lowest value appeared in June and July, and the highest generally appeared in January and December; temperature and precipitation affect seasonal changes in $\mathrm{SO}_{2}$ concentration, and both had a significant negative correlation with $\mathrm{SO}_{2}$ concentration.

4) The overall trends in the average annual value of $\mathrm{SO}_{2}$ in the 13 cities appear to have decreased since 2007, energy consumption may be an important factor in $\mathrm{SO}_{2}$ concentration changes, and the $\mathrm{SO}_{2}$ concentration in the Shijiazhuang-Xingtai-Handan region decreased by $55 \%$ during the past decade, so the Chinese government has made great efforts in pollution reduction and has achieved remarkable results.

\section{Acknowledgements}

This research was supported by the National Key Research and Development Plan (No. 2016YFC050350703) and the major National Projects (No. 00-Y30B149001-14/16). We would like to thank NASA/OMI for providing SO2 data. We also thank the National Climate Center of China for temperature and precipitation datasets.

\section{References}

1. LAL C.M.S. Seasonal characteristics of $\mathrm{SO}_{2}, \mathrm{NO}_{2}$, and $\mathrm{CO}$ emissions in and around the Indo-Gangetic Plain. Environmental Monitoring and Assessment, 186, 1295, 2014.

2. KROTKOV N.A., MCLINDEN C.A., LI C., LAMSAL L.N., CELARIER E.A., MARCHENKO S.V., SWARTZ W.H., BUCSELA E.J., JOINER J., DUNCAN B.N., BOERSMA K.F., VEEFKIND J.P., LEVELT P.F., FIOLETOV V.E., DICKERSON R.R., HE H., LU Z., STREETS D.G. Aura OMI observations of regional $\mathrm{SO}_{2}$ and $\mathrm{NO}_{2}$ pollution changes from 2005 to 2015. Atmospheric Chemistry and Physics, 16, 4605, 2016.

3. LU Z., ZHANG Q., STREETS D.G. Sulfur dioxide and primary carbonaceous aerosol emissions in China and India, 1996-2010. Atmospheric Chemistry and Physics, 11, 9839-, 2011.

4. MENG Z.Y., DING G.A., XU X.B., XU X.D., YU H.Q., WANG S.F. Vertical distributions of $\mathrm{SO}_{2}$ and $\mathrm{NO}_{2}$ in the lower atmosphere in Beijing urban areas, China. Science of the Total Environment, 390, 456, 2008.

5. SUN Y., WANG Y., ZHANG C. Measurement of the vertical profile of atmospheric $\mathrm{SO}_{2}$ during the heating period in Beijing on days of high air pollution. Atmospheric Environment, 43, 468, 2009.

6. LI C., ZHANG Q., KROTKOV N.A., STREETS D.G., HE K., TSAY S., GLEASON J.F. Recent large reduction in sulfur dioxide emissions from Chinese power plants observed by the Ozone Monitoring Instrument. Geophysical Research Letters, 37, L08807, 2010.

7. MENG Z.Y., XU X.B., WANG T., ZHANG X.Y., YU X.L., WANG S.F., LIN W.L., CHEN Y.Z., JIANG Y.A., AN X.Q. Ambient sulfur dioxide, nitrogen dioxide, and ammonia at ten background and rural sites in China during 20072008. Atmospheric Environment, 44, 2625, 2010.

8. IALONGO I., HAKKARAINEN J., KIVI R., ANTTILA P., KROTKOV N.A., YANG K., LI C., TUKIAINEN S., HASSINEN S., TAMMINEN J. Comparison of operational satellite $\mathrm{SO}_{2}$ products with ground-based observations in northern Finland during the Icelandic Holuhraun fissure eruption. Atmospheric Measurement Techniques, 8, 2279, 2015.

9. LU Z., STREETS D.G., ZHANG Q., WANG S., CARMICHAEL G.R., CHENG Y.F., WEI C., CHIN M., DIEHL T., TAN Q. Sulfur dioxide emissions in China and sulfur trends in East Asia since 2000. Atmospheric Chemistry and Physics, 10, 6311, 2010.

10. GAO C., YIN H., AI N., HUANG Z. Historical Analysis of $\mathrm{SO}_{2}$ Pollution Control Policies in China. Environmental Management, 43, 447, 2009.

11. ZHANG Q., GENG G., WANG S., ANDREAS R., HE K. Satellite remote sensing of changes in NOx emissions over China during 1996-2010. Chinese Science Bulletin, 57, 2857, 2012.

12. ZHOU Y., BRUNNER D., HUEGLIN C., HENNE S., STAEHELIN J. Changes in OMI tropospheric $\mathrm{NO}_{2}$ columns over Europe from 2004 to 2009 and the influence of meteorological variability. Atmospheric Environment, 46, 482, 2012.

13. JIN J., MA J., LIN W., ZHAO H., SHAIGANFAR R., BEIRLE S., WAGNER T. MAX-DOAS measurements and satellite validation of tropospheric $\mathrm{NO}_{2}$ and $\mathrm{SO}_{2}$ vertical column densities at a rural site of North China. Atmospheric Environment, 133, 12, 2016.

14. KRUEGER A., KROTKOV N., CARN S. El Chichon: The genesis of volcanic sulfur dioxide monitoring from space. Journal of Volcanology \& Geothermal Research, 2008.

15. FIOLETOV V.E., MCLINDEN C.A., KROTKOV N., LI C., JOINER J., THEYS N., CARN S., MORAN M.D. A global catalogue of large $\mathrm{SO}_{2}$ sources and emissions derived from the Ozone Monitoring Instrument. Atmospheric Chemistry and Physics, 16, 11497, 2016.

16. WANG Y., JIANG H., ZHANG S., XU J., LU X., JIN J., WANG C. Estimating and source analysis of surface PM2.5 concentration in the Beijing-Tianjin-Hebei region based on MODIS data and air trajectories. International Journal of Remote Sensing, 37, 4799, 2016.

17. LEVELT P.F., VAN DEN OORD G.H.J., DOBBER M.R., MALKKI A., VISSER H., DE VRIES J., STAMMES P., LUNDELL J., SAARI H. The Ozone Monitoring Instrument. IEEE Transactions on Geoscience \& Remote Sensing, 44 (5), 1093, 2006.

18. LEVELT P.F., HILSENRATH E., LEPPELMEIER G.W., VAN DEN OORD G.H.J., BHARTIA P.K., TAMMINEN J., DE HAAN J.F., VEEFKIND J.P. Science Objectives of 
the Ozone Monitoring Instrument. IEEE Transactions on Geoscience \& Remote Sensing, 44 (5), 1199, 2006.

19. DUBOVIK O., KING M.D. A flexible inversion algorithm for retrieval of aerosol optical properties from Sun and sky radiance measurements, Journal of Geophysical Research, 105 (D16), 20, 673-20, 696, 2000.

20. CHANCE K. OMI Algorithm Theoretical Basis Document, Volume IV, OMI Trace Gas Algorithms. ATBD-OMI-02, Version 2.0, August 2002.

21. KROTKOV N.A., CARN S.A., KRUEGER A.J., BHARTIA P.K., YANG K. Band residual difference algorithm for retrieval of $\mathrm{SO}_{2}$ from the Aura Ozone Monitoring Instrument (OMI). IEEE Transactions on Geoscience \& Remote Sensing. AURA special issue, 44 (5), 1259, 2006.

22. KRUEGER A.J., WALTER L.S., BHARTIA P.K., SCHNETZLER C.C., KROTKOV N.A., SPROD I., BLUTH G.J.S. Volcanic sulfur dioxide measurements from the total ozone mapping spectrometer instruments. Journal of Geophysical Research, 100 (D7), 14057, 1995.

23. KRUEGER A.J., KROTKOV N.A., DATTA S., FLITTNER D., DUBOVIK O. $\mathrm{SO}_{2}$, in Algorithm Theoretical Baseline Document: OMI Trace Gas Algorithms, K. Chance (ed.), vol. IV, ATBD-OMI-04, version 2.0, Aug. 2002.

24. KROTKOV N.A., LI C., LEONARD P. OMI/Aura Sulfur Dioxide $\left(\mathrm{SO}_{2}\right)$ Total Column L3 1 day Best Pixel in 0.25 degree x 0.25 degree V3, Greenbelt, MD, USA, Goddard Earth Sciences Data and Information Services Center (GES DISC), 2015.
25. JIANG J., ZHA Y., GAO J., JIANG J. Monitoring of $\mathrm{SO}_{2}$ column concentration change over China from Aura OMI data. International Journal of Remote Sensing, 33 (6), 1934, 2012.

26. KROTKOV N.A., MCCLURE B., DICKERSON R.R., CARN S.A., LI C., BHARTIA P.K., YANG K., KRUEGER A.J., LI Z., LEVELT P.F., CHEN H., WANG P., LU D. Validation of $\mathrm{SO}_{2}$ retrievals from the Ozone Monitoring Instrument over NE China. Journal of Geophysical Research, 113, D16S40, 2008.

27. ZHANG X., GEFFEN J., LIAO H., ZHANG P., LOU S. Spatiotemporal variations of tropospheric $\mathrm{SO}_{2}$ over China by SCIAMACHY observations during 2004-2009. Atmospheric Environment, 60, 238-, 2012.

28. WANG S., HAO J. Air quality management in China: Issues, challenges, and options. Journal of Environmental Sciences, 24 (1), 2, 2012.

29. ZHAO B., WANG S., WANG J., FU J.S., LIU T., XU J., FU $\mathrm{X}$., HAO J. Impact of national $\mathrm{NO}_{\mathrm{x}}$ and $\mathrm{SO}_{2}$ control policies on particulate matter pollution in China. Atmospheric Environment, 77, 453, 2013.

30. WANG S., ZHANG Q., MARTIN R.V., PHILIP S., LIU F., LI M., JIANG X., HE K. Satellite measurements oversee China's sulfur dioxide emission reductions from coal-fired power plants. Environmental Research Letters, 10, 114015, 2015. 
